\title{
SÍKKEREKES HULLÁMHAJTÓMÜ CSALÁD KÍSÉRLETI FEJLESZTÉSE ÉS PROTOTÍPUSGYÁRTÁSA A K.K.K. 99 KFT.-NÉL
}

\author{
Krisch Róbert \\ ügyvezetö, K.K.K. 99 Kft. \\ 9500 Celldömölk, Nagy Sándor tér 1., e-mail: info@kkk99.hu \\ Göncfalvi Balázs \\ projektvezetö, K.K.K. $99 \mathrm{Kft}$. \\ 9500 Celldömölk, Nagy Sándor tér 1., e-mail: info@kkk99.hu
}

\begin{abstract}
Absztrakt
A síkkerekes hullámhajtómüvek müködési elve nagymértékben hasonlit a hagyományos hengeres kerekes hullámhajtómüvekéhez, csupán az alapelemek kialakitásában térnek el egymástól. Jelen cikk kísérleti síkkerekes hullámhajtómüvek különbözö változatainak kifejlesztését, valamint az elkészült hajtómüveken végzett teszteket és eredményeket hivatott bemutatni. A projekt a Gazdaságfejlesztési és Innovációs Operativ Program keretei között, a Nemzetgazdasági Minisztérium és az Európai Unió támogatásával jöhetett létre.
\end{abstract}

Kulcsszavak: kutatás-fejlesztés, hullámhajtómü, Nemzetgazdasági Minisztérium

\begin{abstract}
The functions of the principal members of a flat-wheel harmonic drive are similar to the functions of a traditional harmonic drive, but the feature of the flexible and the solid wheels are different. This paper reports the development and investigations of the pertain conditions of different variations of experimental flat wheel harmonic drives. The development project was sponsored by Ministry for National Economy and European Union.
\end{abstract}

Keywords: development and investigation, harmonic drive, Ministry for National Economy

\section{Bevezetés}

A K.K.K. 99 Kft. a GINOP 2.1.7-15-2016-00507 sz. pályázat keretében támogatást nyert síkkerekes hullámhajtóművek fejlesztésére és prototípusainak legyártására. A fogazati paraméterek és az ideális deformált alak rögzítése mellett a fejlesztés tárgyát képező precíziós hajtásrendszerek alapelemeinek és föbb alkatrészeinek kialakítása nagymértékben befolyásolja a berendezés müködését, illetve annak gyártási költségeit. Jelen cikk az ezen elemek kombinálásából előállítható potenciális hajtásrendszerek kifejlesztését mutatja be, egészen a tesztek elvégzéséig és kiértékeléséig. Célunk olyan síkkerekes hullámhajtómüvek megtervezése, gyártása és tesztelése volt, amelyek a jelenleg kapható hengeres kerekes társaik alternatívájaként, versenytársaként szolgálhatnak. 


\section{A síkkerekes hullámhajtómű alapelemei és működése}

A vizsgált síkkerekes hullámhajtómü tulajdonképpen a hengeres kerekes fogaskerék-hullámhajtómü (harmonic-drove.com) egy speciális változatának tekinthető, amelyben a behajtó oldalon forgó mozgást végző, bütyökfelülettel ellátott hullámgenerátor (4) egy rugalmas axiális csapágyon keresztül (3) deformálja a szintén rugalmas hullámkereket (2), amely ezáltal a merev kerékkel (1) kapcsolódik. Ezek a hajtómü ún. alapelemei, amelyek koaxiális elrendezésủek, és az 1. ábrán láthatók.

Kéthullámú hajtómü esetében a fogazott elemek kapcsolódása két ellentétes oldalon jön létre, amelynek következménye, hogy a hullámgenerátor egy körülfordulása a rugalmas tagon csupán két fogosztásnyi elmozdulást eredményez. Megállapítható, hogy ez a kialakítás meglehetősen nagy áttételt (akár i = 80-320) eredményezhet. (Krisch, 2010)

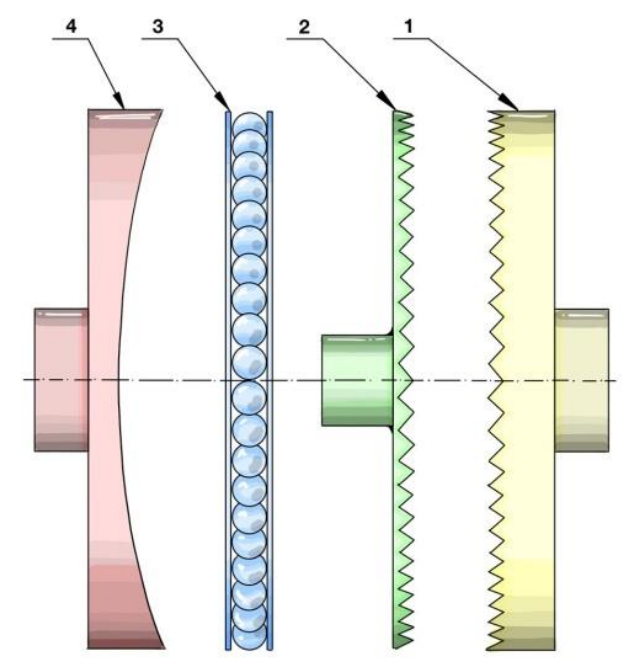

1. ábra. A síkkerekes hullámhajtómü alapelemei: merev kerék (1), hullámkerék (2), rugalmas csapágy (3,) bütykös hullámgenerátor (4)

A megfelelö müködéshez elkerülhetetlen, hogy a rugalmas és merev kerék kapcsolódásának paraméterei (deformáció mértéke, fogprofilok, foghézagok nagysága stb.) biztosítsák a két fogazott alapelem fogfej-ütközés és fogfej-interferencia nélküli kapcsolódását. A fogazat geometriája egy korábbi tanulmányban (Krisch, 2010) összeállított fogkapcsolódási és deformációs modellen, illetve egy ehhez köthető kutatásunk (Kardos és Krisch, 2018) alapján került kialakításra, a rugalmas kerék deformált alakjának pontos megismeréséhez pedig végeselemes módszert alkalmaztunk.
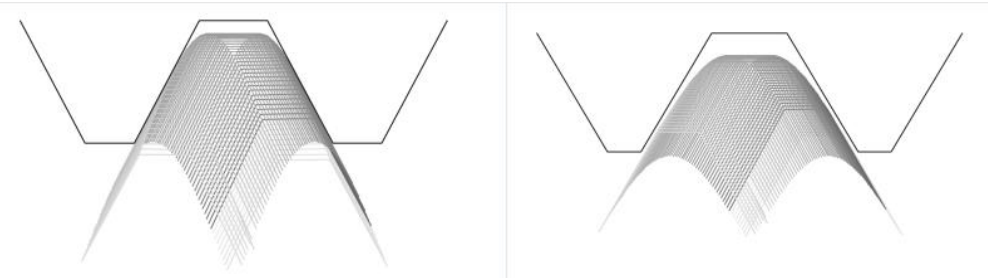

2. ábra. Hullámkerék egy fogának pályája a merevkerék fogárkában külső (bal) és belsö (jobb) peremen terheletlen állapotban 


\section{Fejlesztési fázisok ismertetése}

Az analitikus és végeselemes számítások eredményeinek validálásához a valós körülmények között elvégzett tesztek nélkülözhetetlenek, ezért a kutatás fejlesztési projekt célja tesztelt prototípusok előállítása volt. A vizsgálatokhoz szükséges alkatrészek gyártását koncepcionális tervezési fázis előzte meg, amelynek során gyárthatósági, szerelhetőségi, illetve további, költségekhez köthető szempontok szerint kerültek kiválasztásra a legjobbnak ítélt alkatrész-geometriák és elemkombinációk. Ezt követően a müködést befolyásoló részegységekböl több verzió is legyártásra került, amelyeket kombinálva összesen $7 \mathrm{db}$ különböző hajtómü változat tesztelését végezhettük el. Az eredmények ismeretében meghatározható az egyes alkatrészek müködésre gyakorolt hatása, széleskörü képet kaphatunk a fejlesztés tárgyát képező hajtómütípusok főbb tulajdonságairól, előnyeiről-hátrányairól. Ezen ismeretek hozzájárulnak a hajtómüvek piaci pozícionálásához és a lehetséges alkalmazási területek feltárásához.

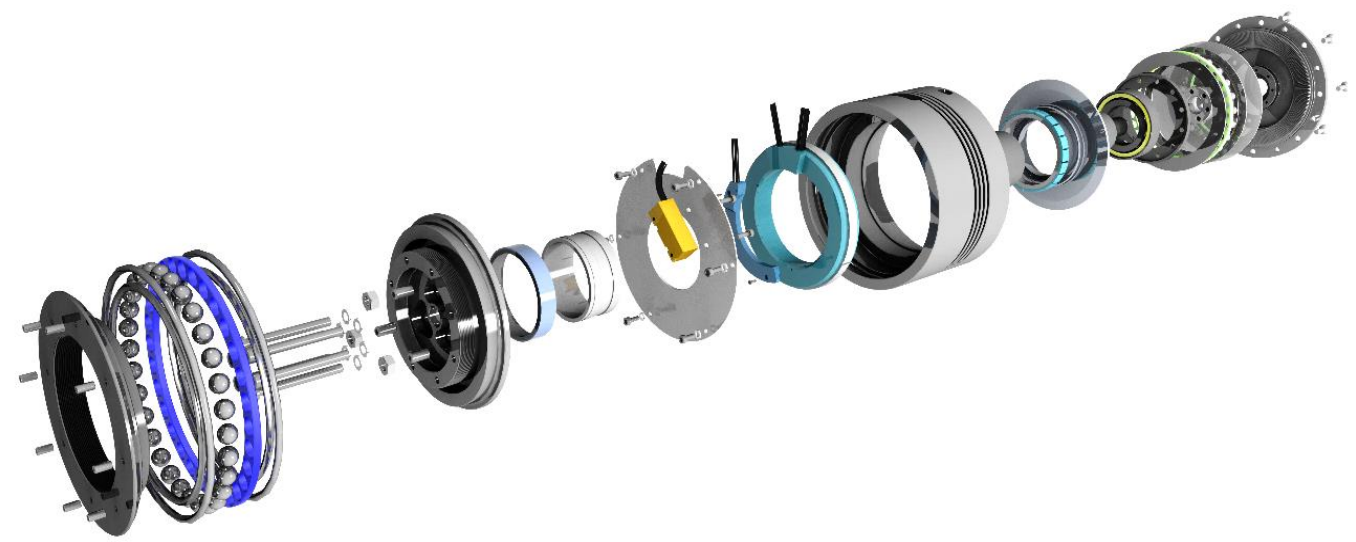

3. ábra. A kisérleti síkkerekes hullámhajtómü robbantott ábrája

\section{Koncepcionális tervezés, kiválasztott hajtómü kombinációk}

Az irodalomkutatás során különböző precíziós hajtómü típusok összehasonlító elemzésére és értékelésére került sor. Ennek keretei között kiválasztottuk a megtartandó müszaki megoldásokat és kombinációkat, amelyek az élettartamra vetítve költséghatékonyan elégítik ki az elöírt követelményeket, valamint kereskedelmi tételek, anyagok, kenőanyagok, kötőelemek terén is széles választék állt rendelkezésünkre.

Első lépésként az 1. ábrán bemutatott négy alapelem megfelelő csapágyazásáról kellett gondoskodni. Ezt követően egy sztátor és egy rotor gyürüből álló ún. nyomatékmotor került beépítésre, amely igen kompakt kialakítású, ugyanakkor kizárólag a gyártó által előírt szigorú kritériumok szerint építhető be. Végül a hajtómüház folyamatos fejlesztésével, illesztőfelületek és állítási lehetőségek kialakításával, elektronikai elemek és szenzorok integrálásával állt össze a végleges hajtómü koncepció, amelynek metszeti képe a 4. ábrán látható. Fontos megjegyezni, hogy a hajtómü megfelelö merevségét különleges, ún. drótcsapágyazással biztosítottuk.

Az alapelemek közül több típus is legyártásra került, így 120 és 160-as áttételü hajtómü is összeállítható, a hullámgenerátorok eltérő bütyökfelülettel, a rugalmas csapágyak pedig többféle gyürüvel és horonymélységgel készültek el. Mindemellett három különböző jeladó típus, illetve bordázott és bordázatlan hajtómüházak is rendelkezésünkre álltak. 

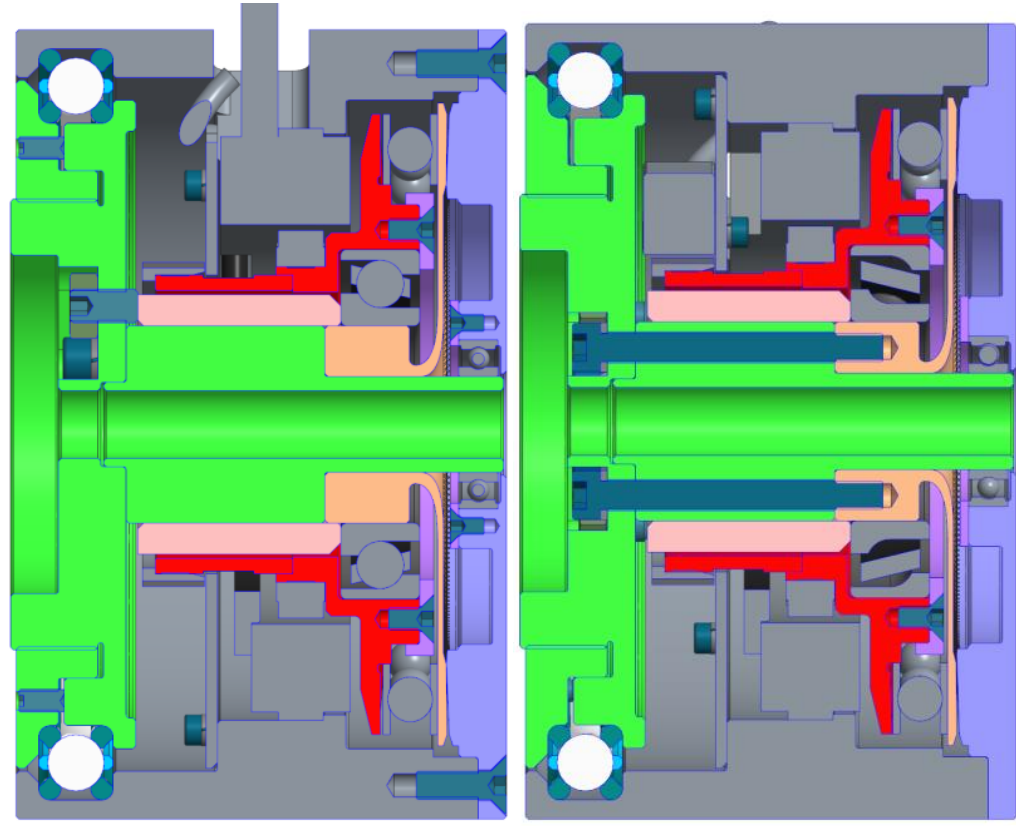

4. ábra. A kisérleti síkkerekes hullámhajtómü végleges verziójának metszete

\section{Mérési összeállítás és alkalmazott mérőeszközök}

A hajtómükombinációk azonos körülmények között történő vizsgálatához összeállításra került egy robusztus tesztkeret, amely az 5 . ábrán látható. A lemez vázra szerelt hajtásrendszerek járatás közben acél féktárcsán és réz fékpofákon keresztül-, egy merev acél kar segítségével pedig álló helyzetben és kis mozgástartományon terhelhetők.

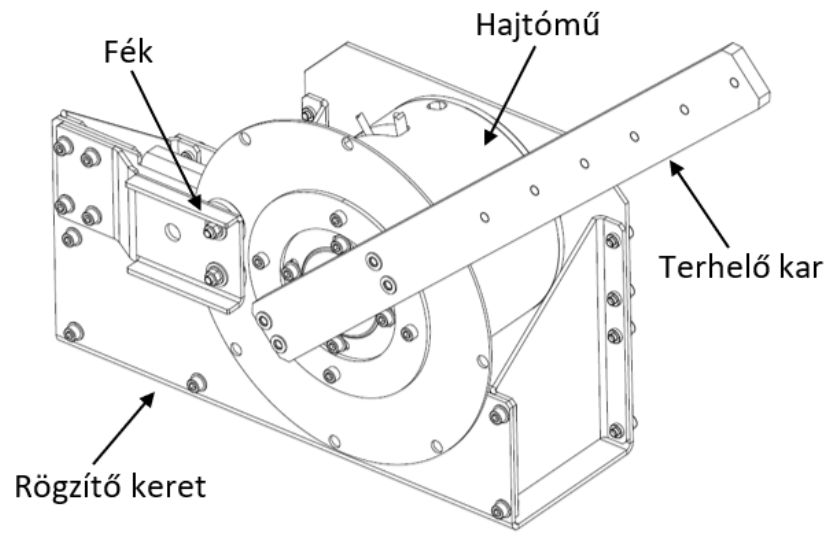

5. ábra. Kisérleti hajtásrendszerek vizsgálatára szolgáló tesztberendezés

A terhelő kar végpontján finomtapintó mérőórával mérjük az elmozdulást. A rendszer merevségének meghatározásához és a hajtómü rugalmas deformációjának kiküszöböléséhez a hajtómüház helyére egy kielégítően merev, megegyező méretű elemet helyzetünk, amelyet egy kar segítségével külpontosan terheltünk. Ezzel megállapítottuk a rendszer (asztal, mérö keret, kar adapter, 
kar) lehajlását, így ezen érték és a mért torziós merevség különbsége a hajtóművek tényleges torziós merevsége. A mérések során rögzítésre kerül a nyomaték tartásához szükséges áramerősség értéke, emellett a mért lehajlásértékekből adódik a hajtásrendszerek szögmerevsége.

Ugyanezen mérési elrendezésnél mérhető a visszaállási pontosság, amely a precíziós hajtásrendszerek esetében kulcsfontosságú paraméter. Ehhez rögzített terhelőnyomaték mellett vízszintes helyzetből $-30^{\circ}$-ba, majd újra a kiindulási pozícióba vezérelve a motort finomtapintó segítségével mértük a függőleges irányú elmozdulást, illetve számítottuk a visszaállási szöghibát.

A hajtásrendszerek alkalmazási területei között szerepelnek olyan felhasználási módok, amelyeknél a hajtásrendszer tartós járatásnak van kitéve. Ennek szimulálásához fokozatosan növelt fordulatszám és állandó terhelés mellett vizsgáltuk a felvett áramerősséget, a hajtóműház- és a motor hőmérsékletét, valamint a hajtásrendszer zajszintjét. A hőmérséklet változását a multiméter ellenállás alapú hőszondájával, a hőmérséklet eloszlását pedig hőkamerával mértük. A zajszintet hangnyomásmérővel regisztráltuk, azonban itt fontos megjegyezni, hogy a kapott értékek tartalmazzák a környezö szerelvények által felerősített rezgéseket is, így ezek csupán összehasonlításra alkalmasak.
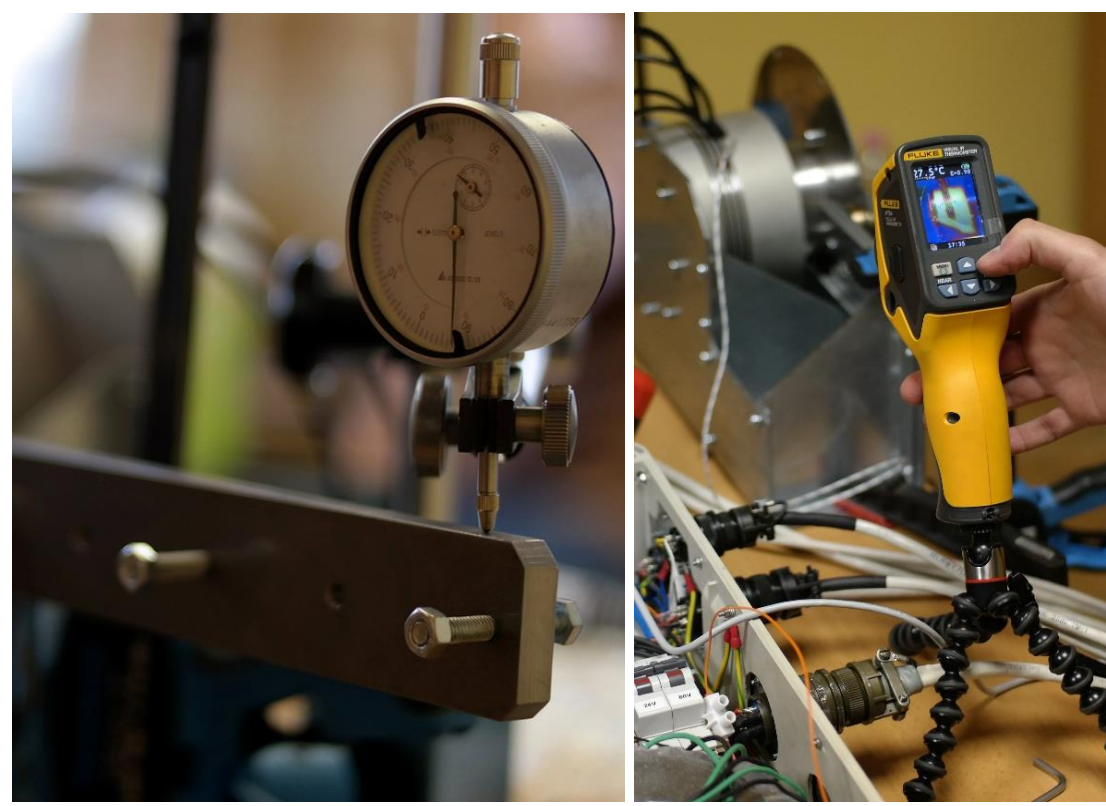

6. ábra. Lehajlás és visszaállási pontosság mérése finomtapintóval, hömérsékleteloszlás mérése hökamerával

\section{Mérési eredmények}

A tesztek során hét különböző hajtómü-konfigurációt vizsgáltunk. Az eltérő verziók az alább látható konfigurációs táblázat elemeinek kiválasztásából és összeállításából épültek fel.

$\mathrm{Az}$ eredmények nyomon követhetösége érdekében egységes mérési jegyzőkönyvet állítottunk össze. A jegyzőkönyv minden esetben tartalmazza a hajtómü építőelemeinek jelölését, valamint a visszaállási pontossághoz, torziós merevséghez, és tartós járatáshoz kapcsolódó értékeket. Minden hajtómü mérése során digitális oszcilloszkópon volt lehetőségünk az áramfelvételhez, feszültséghez, forgási sebességhez és egyéb paraméterekhez tartozó cél és mért értékek közötti eltérést az idő függvényében nyomon követni. Megfigyelhető volt például, hogy magasabb fordulatszám 
tartományok esetén erősebb szabályozásra van szükség, amelynek oka a ferdehatásvonalú csapágy enyhe ütésére volt visszavezethetö.

1. táblázat. Hajtómü konfigurációs táblázat

\begin{tabular}{|c|c|c|c|}
\hline Hullámgenerátor: & $2^{\circ}$ golyós & $2.3^{\circ}$ golyós & $2^{\circ}$ görgős \\
\hline Csapággyűrű: & \multicolumn{2}{|c|}{$1.25-0.4 \mathrm{~mm}$} & $1.4-0.5 \mathrm{~mm}$ \\
\hline Encoder: & Inkr. D20 & Inkr. D80 & Analóg $+1 \mathrm{dx}$ \\
\hline Áttétel: & \multicolumn{2}{|c|}{120} & 160 \\
\hline Ház: & \multicolumn{2}{|c|}{ Bordázott } & dázatlan \\
\hline
\end{tabular}

A mérések kiértékelésével számos értékes tapasztalatot szereztünk. Az analóg jeladóval szerelt verziók tesztelése megmutatta, hogy bár a hajtásrendszerek rövid ideig müködtethetők, magasabb áramfelvétel és a hőmérséklet növekedése mellett a rendszer elveszti a fordulatszám visszacsatolás jelét, kiszámíthatatlanul viselkedik. Ezáltal valós eredményeket csupán a digitális jeladóval szerelt egységekből nyerhettünk. A 160-as áttételü hajtásrendszerek esetében ugyan valamivel magasabb áramfelvétel volt tapasztalható, azonban magas fordulaton is alacsonyabb zajjal járt a hajtómüvek müködése, mint a 120-as áttételüeké. A hőkamerás felvételeken tisztán látható, hogy a bordázott ház nagymértékben hozzájárul a motor hütéséhez.

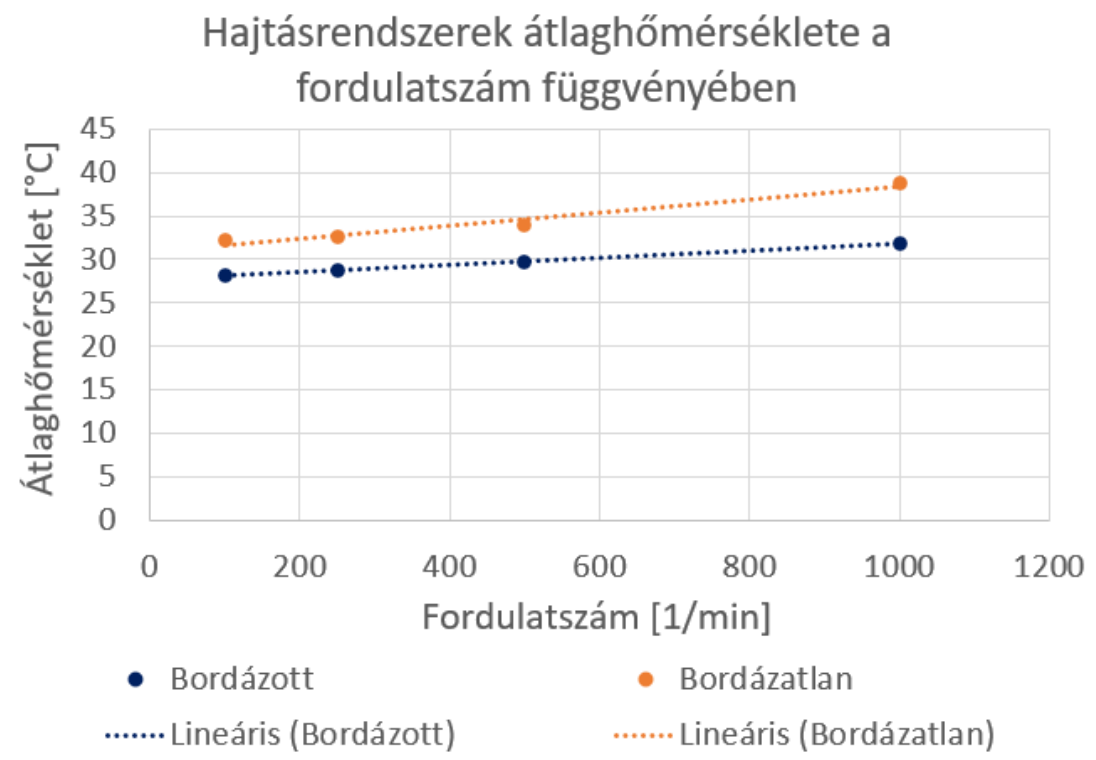

7. ábra. Bordázott és bordázatlan ház hömérséklete a fordulatszám függvényében

A visszaállási pontosság mérése megmutatta, hogy a nagyobb felbontású D80-as enkóder D20-asra történő cseréje semmilyen, a müködést érdemben befolyásoló hatással nem járt, hiszen 160-as áttételü hajtómủvek esetében több alkalommal is csekély, 1 szögperc alatti visszaállási hibát tapasztaltunk. A görgős ferdehatásvonalú csapágy szerelése nehézkes, és bár a hajtómüvek zajszintje a beépítést 
követően csökkent, a golyóscsapágyakkal szerelt változatokhoz képest nagymértékü ütés és magas, ráadásul egyenetlenebb áramfelvétel volt tapasztalható.

\section{Létjogosultság a piacon}

Belátható, hogy a kereskedelmi forgalomban kapható precíziós hajtásrendszerek esetében a 120 -as és 160-as áttétel igen magas érték, ezen a területen fơként a bolygóműves hajtások terjedtek el. Tovább szükíthető a konkurens termékek palettája, amennyiben figyelembe vesszük, hogy jelen hajtómü szervo hajtással szerelt, ezáltal önálló egységként telepíthető, ennek ellenére mindössze $\varnothing 133 \times 100$ [mm] befoglaló méretekkel rendelkezik.

Az átlagos visszaállási pontosság 0,7 [szögperc], amely meglehetősen jó értéknek számít. A torziós merevség átlaga 6,2 [Nm/szögperc] feletti érték, amely megközelíti a Bonfiglioli precíziós bolygómüvek (bonfiglioli.com) hasonló teljesítményü egységeinek szintjét.

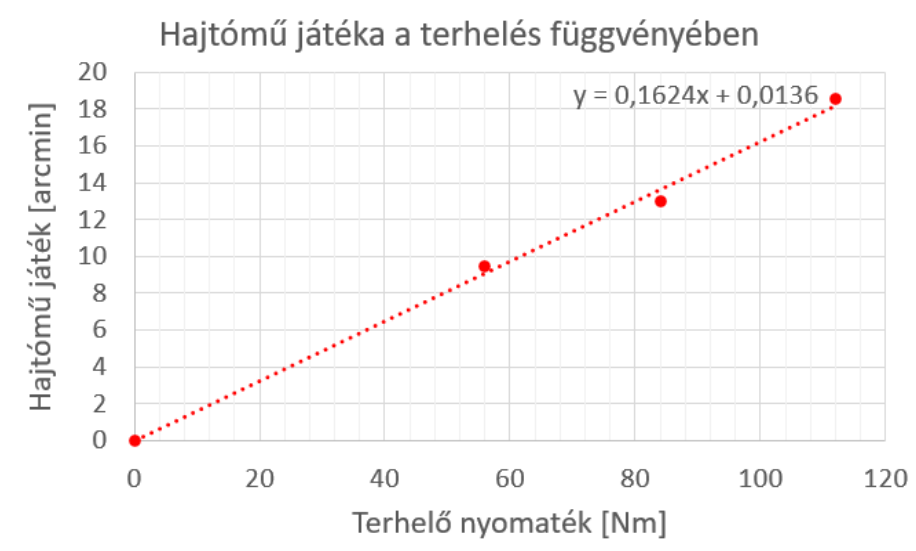

8. ábra. Hajtómü játéka a terhelö nyomaték függvényében

A vizsgált hajtómüvek egyik nagy előnye, hogy esetükben a fogazat kapcsolódása fokozatmentesen állítható, ezáltal a kihajtás teljesen játékmentessé tehető. Ezt jól szemlélteti a 8. ábra, amelyen látható, hogy a holtjáték $10[\mathrm{Nm}$ ] terhelésig 2 [szögperc] alatt marad, amellyel megelözi a Bonfiglioli hajtómüvek 4-6 [szögperc]-es értékeit (bonfiglioli.com).

\section{8. Összefoglalás és fejlesztési lehetőségek}

A hullámhajtóművek tesztelése számos tapasztalattal járt, melyek hozzásegíthetnek újabb prototípusok, ezáltal egy kiforrottabb termék megalkotásához. Célul tủztük ki, hogy integráljunk olyan változtatásokat, amelyek javítják a berendezés paramétereit. Az axiális csapágyban alkalmazott kisebb átmérỏjü gördülőelemekkel javíthatók a futási tulajdonságok, a fogazott elemek súrlódásának csökkentése érdekében pedig kézenfekvő megoldás lehet az olajkenés alkalmazása. Utóbbi esetében feladatunk a hajtásrendszer teljeskörü tömítettségét biztosítani, így csökkenthető a súrlódásból adódó veszteség és a hajtómü zajszintje, ráadásul ez a fejlesztés a hőelvezetésre is kedvező hatással lenne. A vizsgált hajtómüvek mindegyike megegyező méretü, azonban az eltérő felhasználási igényekhez igazodva a későbbiekben akár egy termékcsalád összeállítására is van lehetőség. 


\section{Irodalom}

[1] www.harmonic-drive.com

[2] Krisch, R. (2010). Síkkerekes hullámhajtó-müvek fejlesztése. PhD értekezés, BME.

[3] Kardos, Sz., Krisch, R. (2018). Síkkerekes hullámhajtómü fejlesztése a K.K.K. 99 Kft-nél. $G E ́ P$, LXIX(2018/4), 41.

[4] www.bonfiglioli.com 